\title{
Functional traits of a broad-niched metallophyte along a toxicity gradient: disentangling intra and inter-population variation
}

\author{
Guillaume Delhaye $^{\mathrm{a}, *}$, Bastien Lange ${ }^{\mathrm{b}}$, Michel-Pierre Faucon ${ }^{\mathrm{b}}$, Céline Grandjean ${ }^{\mathrm{a}}$, Gregory Mahy ${ }^{\mathrm{c}}$, \\ Pierre Meerts ${ }^{\mathrm{a}}$

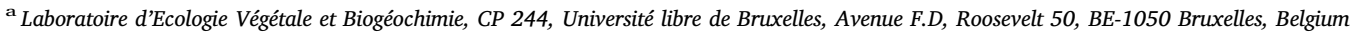 \\ ${ }^{\mathrm{b}}$ Agroécologie, Hydrogéochimie, Milieux et Ressources) (AGHYLE), Institut Polytechnique UniLaSalle, 19 rue Pierre Waguet, FR-60026 Beauvais, France \\ ${ }^{\mathrm{c}}$ Department of Forest, Nature and Landscape. Biodiversity and Landscape unit, University of Liège, Gembloux Agro-Bio Tech, 2 Passage des Déportés, 5030 Gembloux, \\ Belgium
}

\section{A R T I C L E I N F O}

\section{Keywords:}

Metal gradient

Facultative metallophyte

Intraspecific variation

Copper availability

Phenotypic plasticity

\begin{abstract}
A B S T R A C T
Studies on the relative contribution of inter- and intra-population trait variations in broad-niched species along edaphic gradients are still scarce. Here, we explore the variation of eight traits in five populations of Cyanotis longifolia, a broad-niched metallophyte thriving on very broad gradients of soil copper concentration in Central Africa. Variation at species level was decomposed into covariation with copper, variation among sites, and residual variation. The proportion of the variance explained by the site and by the local copper gradient in each site ranged from 10 to $32 \%$ and between 5 and 51\% respectively, depending on trait. At the species level, specific leaf area decreased and leaf $\mathrm{Cu}$ and $\mathrm{Co}$ concentrations increased with increasing soil $\mathrm{Cu}$ concentration. Surprisingly, traits related to plant size show a quadratic response with higher values on both high and low soil $\mathrm{Cu}$ concentrations. This could be accounted for by population-specific patterns of covariation with soil copper. Population specific traits responses were found, with some populations exhibiting no significant response while the others sometimes show opposing variation patterns. The reasons for such idiosyncratic patterns are discussed in terms of interactions with other soil factors influencing $\mathrm{Cu}$ availability and toxicity. In further studies on trait variation along toxicity gradients, we recommend to investigate the small scale edaphic variability and to measure traits at the population level to capture the diversity of functional responses.
\end{abstract}

\section{Introduction}

Within species variation in functional traits is now recognised as an important component of community trait variation and community assembly processes (Siefert et al., 2015; Hart et al., 2016). It is composed of both within population and between population variations. Most studies focus on between population trait variation along altitudinal and latitudinal gradients (Souto et al., 2009; Fajardo and Piper, 2011) but studies comparing within species variation along several similar environmental gradients are scarce. However, growing evidence indicates that intra-population variation can be as large as inter-population variation along soil depth, light, temperature, nutrients or altitude gradients (Bresson et al., 2011; Wellstein et al., 2013; Lemke et al., 2015; Harzé et al., 2016; Pfennigwerth et al., 2017). This can result from two, mutually non exclusive mechanisms i.e. phenotypic plasticity (e.g. Valladares et al., 2014) and local genetic variation (e.g. Byars et al., 2007; Robson et al., 2012). Both genetic and phenotypic differences of adaptive traits have been documented at very small spatial scales (Bradshaw, 1959; Linhart and Grant, 1996), particularly in relation to metallic trace elements (MTE) enriched soils (Antonovics et al., 1971; Al-Hiyaly et al., 1993).

Soil metal contamination represents stringent selective pressure that can promote the evolution of locally adapted ecotypes (Słomka et al., 2011; Wójcik et al., 2015). Plant evolutionary ecology studies often compare metallicolous and non metallicolous populations, based on the assumption that the differences in ecological conditions between MTEenriched site and the non-contaminated neighbourhood produce a clear-cut difference in plant phenotype. However, soil conditions are often extremely variable both among and within metalliferous sites which can lead to intraspecific differences in tolerance strategies, ion contents or functional traits values (Lefebvre, 1974; Lange et al., 2017b; Stein et al., 2017; Frérot et al., 2018). Although metallophytes tolerance

\footnotetext{
* Corresponding author.

E-mail addresses: guildelhaye@gmail.com (G. Delhaye), bastien.lange@unilasalle.fr (B. Lange), michel-pierre.faucon@unilasalle.fr (M.-P. Faucon), grandjean.celine@education.lu (C. Grandjean), g.mahy@ulg.ac.be (G. Mahy), pmeerts@ulb.ac.be (P. Meerts).
} 
Table 1

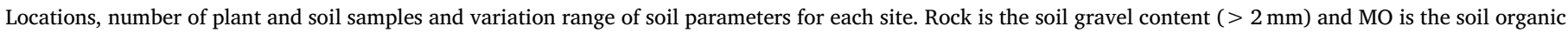
matter content, both expressed in percentage of soil mass. $\mathrm{Ca}, \mathrm{Co}, \mathrm{Cu}, \mathrm{Fe}, \mathrm{K}, \mathrm{Mg}, \mathrm{Mn}$ and $\mathrm{P}$ are expressed in mg kg ${ }^{-1}$ (Ac-EDTA extractable).

\begin{tabular}{|c|c|c|c|c|c|}
\hline & Goma & Orthodoxe & Zikule & Kinsevere & Fungurume \\
\hline Coordinates & $\mathrm{S} 10^{\circ} 35^{\prime} 56^{\prime \prime} \mathrm{E} 26^{\circ} 08^{\prime} 20^{\prime \prime}$ & $\mathrm{S} 10^{\circ} 36^{\prime} 26^{\prime \prime} \mathrm{E} 26^{\circ} 07^{\prime} 37^{\prime \prime}$ & $\mathrm{S} 10^{\circ} 38^{\prime} 48^{\prime \prime} \mathrm{E} 26^{\circ} 12^{\prime} 48^{\prime \prime}$ & $\mathrm{S} 11^{\circ} 21^{\prime} 58^{\prime \prime} \mathrm{E} 27^{\circ} 34^{\prime} 53^{\prime \prime}$ & $\mathrm{S} 10^{\circ} 36^{\prime} 47^{\prime \prime} \mathrm{E} 26^{\circ} 17^{\prime} 10^{\prime \prime}$ \\
\hline Individuals & 65 & 43 & 22 & 45 & 43 \\
\hline Soil samples & 55 & 34 & 20 & 12 & 40 \\
\hline $\mathrm{Cu}\left(\mathrm{mg} \mathrm{kg}^{-1}\right)$ & 30-992 & $36-1409$ & $30-2129$ & $149-6387$ & $218-7758$ \\
\hline $\mathrm{Co}\left(\mathrm{mg} \mathrm{kg}^{-1}\right)$ & $2-111$ & $6-232$ & $8-128$ & $1.5-17$ & $64-850$ \\
\hline $\mathrm{Mn}\left(\mathrm{mg} \mathrm{kg}^{-1}\right)$ & $37-189$ & $65-548$ & $29-502$ & $74-319$ & $37-543$ \\
\hline $\mathrm{Ca}\left(\mathrm{mg} \mathrm{kg}^{-1}\right)$ & $49-593$ & $171-1080$ & $104-458$ & $131-568$ & $72-2359$ \\
\hline $\mathrm{Fe}\left(\mathrm{mg} \mathrm{kg}^{-1}\right)$ & $56-322$ & $158-379$ & $89-367$ & $81-306$ & $26-223$ \\
\hline $\mathrm{K}\left(\mathrm{mg} \mathrm{kg}^{-1}\right)$ & $36-322$ & $79-263$ & $99-281$ & $109-261$ & $32-255$ \\
\hline $\mathrm{Mg}\left(\mathrm{mg} \mathrm{kg}^{-1}\right)$ & $41-300$ & $75-374$ & $71-280$ & $107-364$ & $40-643$ \\
\hline $\mathrm{P}\left(\mathrm{mg} \mathrm{kg}^{-1}\right)$ & $0.9-12.3$ & $1.2-19.1$ & $2.7-17$ & $0.9-36.6$ & $1.9-63.8$ \\
\hline Rock $\left(\mathrm{g} \mathrm{kg}^{-1}\right)$ & $2-730$ & $25-960$ & $100-760$ & $32-670$ & $67-690$ \\
\hline $\mathrm{MO}\left(\mathrm{g} \mathrm{kg}^{-1}\right)$ & $33-75$ & $30-118$ & $57-200$ & $39-166$ & $39-172$ \\
\hline $\mathrm{pH}$ & $5.4-6.4$ & $5.4-6.5$ & $4.6-6.3$ & $5.6-6.1$ & $5.5-7.1$ \\
\hline
\end{tabular}

have been extensively studied from a physiological point of view, most studies on metallophytes have focused on sites that have been recently contaminated by human activities (Baker et al., 2010) and functional traits variation in metallophytes across large gradients of metal concentration in the soil remains largely understudied. Functional traits are expected to vary along toxicity gradients because of selection for optimal trait values in local environments (Garnier et al., 2004) and because of trade-offs between growth or reproduction and metal tolerance (Wilson, 1988; Ernst et al., 1990 but see Harper et al., 1997). Facultative metallophytes along natural MTE gradients offer excellent opportunities to study mechanisms and patterns of trait variation due to soil toxicity, which can be due to phenotypic plasticity or local genetic variation.

In South East of the DR Congo (Upper Katanga), natural outcrops of Cu-rich bedrocks occur in the form of several hundreds of "copper hills". These hills typically appear as islands of herbaceous vegetation emerging from the surrounding woodland matrix (Duvigneaud and Denaeyer-De Smet, 1963). Copper concentration in the soil often increases by three orders of magnitude from the base to the top of the hill (Séleck et al., 2013). Many other chemical and physical factors vary as well, such as phosphorus and organic matter content, and pH (Séleck et al., 2013; Pourret et al., 2016). Each copper hill comprises several habitats, depending mainly on soil $\mathrm{Cu}$ and Co concentrations, as well as other soil chemical or physical properties, slope and microtopography (Duvigneaud and Denaeyer-De Smet, 1963; Saad et al., 2012; Séleck et al., 2013). This variation in MTE concentration in the soil, coupled with the extensive diversity of microhabitats can have a strong influence on the vegetation structure, allowing a large number of species to coexist on a single hill (Saad et al., 2012; Ilunga wa Ilunga et al., 2013; Faucon et al., 2016). Delhaye et al (2016) found clear patterns of variation in community weighted mean values of traits i.e. decreasing leaf area, increasing specific leaf area (SLA, the area of a leaf divided by its dry mass) and foliar MTE content along a gradient of increasing soil Cu. Most of this variation is due to species turn-over along the $\mathrm{Cu}$ gradient. In addition, a number of species occupy a very broad niche along the copper gradient and might exhibit significant intraspecific traits variation. However, $\mathrm{Cu}$ and $\mathrm{Co}$ availability to plants is probably highly variable between sites, depending on the local soil properties and the rhizosphere biogeochemical processes (Lange et al., 2014). Species' functional response to metal concentration in the soil could therefore be highly site-specific. Recent works have found within species variation in $\mathrm{Cu}$ tolerance in this flora, correlated to soil copper content of native sites, suggesting local adaptation (Faucon et al., 2012; Peng et al., 2012; Lange et al., 2018). Therefore, copper hills represent an interesting model to explore trait variation within species along natural MTE gradients.

One of the species with the broadest ecological range on copper hills is Cyanotis longifolia Benth. (Commelinaceae). It is a very polymorphic, self compatible, hemicryptophytic species common in tropical Africa (Owens, 1981; Faden, 2012). C. longifolia is widespread on copper hills and was previously reported as a $\mathrm{Cu}$ and $\mathrm{Co}$ hyperaccumulator (Malaisse et al., 1979). In this paper, we explore the within species variation of functional traits in $C$. longifolia in relation to gradients of soil $\mathrm{Cu}$ concentration. Using populations growing on 5 copper hills, we examine the patterns of traits variation at the species level. Then, we examine the relative contribution of inter- and intra-population functional trait variation along MTE gradients. We test the hypothesis that such variation can be explained by within- and between sites differences in soil available copper content.

More precisely, we ask:

- How do C. longifolia functional traits vary along increasing copper concentration in the soil? We expect a change to traits related to a more stress tolerant strategy with increasing the copper content in the soil.

- What is the relative contribution of intra- versus inter-population variation to the species level variation? We expect the local copper gradient on each site to be the major source of variation in functional traits.

- Do all populations show similar patterns of trait variation along metal gradients? We expect that the soil copper gradient produces a strong filtering effect on functional traits resulting in similar patterns of traits variation between sites.

\section{Material and methods}

\subsection{Study sites}

Five sites were selected in the Copperbelt region in the south-east of D.R. Congo, between Tenke-Fungurume and Lubumbashi (Table 1). Each site was divided in 3 distinct habitats, based on topography and vegetation physiognomy, following Duvigneaud and Denaeyer-De Smet (1963), i.e. from base to top of hill: the dambo (high savannah on horizontal soil around the hill), mid-slope (grassland rich in geofrutex), and the upper slope, (open grassland rich in annual species). From the dambo to the upper part of the slope, soil MTE concentrations increase by two orders of magnitude (Duvigneaud and Denaeyer-De Smet, 1963; Séleck et al., 2013). On each site, a population of $C$. longifolia is present and individuals grow from the bottom to the top of the hills, encompassing a large range of edaphic conditions.

\subsection{Plant sampling and traits measurement}

In January 2013, in each site, individuals of C. longifolia were 
collected along a transect ranging from the bottom to the top of the hill in order to capture the whole range of soil metal concentrations within each site. Population size of $C$. longifolia was small in several sites and habitats. Therefore, sample size did not exceed 10 percent of the individuals in each habitat, i.e. 22 to 65 replicates depending on site (Table 1). Sampled plants were at least $2 \mathrm{~m}$ from each other to avoid multiples samples of the same individual due to vegetative reproduction.

On each individual, 6 functional traits related to size (vegetative height: $\mathrm{VH}$, leaf area: LA, rooting depth: RD), resource use and conservation (specific leaf area: SLA, leaf water content: LWC) and vegetative reproduction (clonal distance: $\mathrm{CD}$ ) were measured. Leaves were collected for determination of concentrations of copper $\left(\mathrm{Cu}_{\mathrm{pl}}\right)$ and cobalt $\left(\mathrm{Co}_{\mathrm{pl}}\right)$. All morphological traits were measured according to PérezHarguindeguy et al (2013) on healthy adult plants with leaves exposed to full sunlight. VH was measured from the base of the plant to the top of the upper leaf. LA was measured on the two, fully developed, youngest undamaged leaves using ImageJ software on photographs of fresh leaves. LWC and SLA were measured on the same leaves after drying at $105^{\circ} \mathrm{C}$ for $48 \mathrm{~h}$. Leaf traits were averaged at the individual level. Recently, Vojtkó et al (2017) emphasized the importance of clonal traits in response to habitat filtering. Therefore, the maximum $\mathrm{CD}$ was measured as the distance between the two farthest ramets of a same individual and the RD was measured after digging up carefully each individual.

Leaves used for SLA measurement were also used to determine MTE concentrations. Fresh leaves were washed in a $1 \%$ Alconox $^{\odot}$ solution, and rinsed (Faucon et al., 2007). The dry samples were ashed at $500{ }^{\circ} \mathrm{C}$ for $12 \mathrm{~h}$. The ashes were diluted in $1 \mathrm{ml}$ of $\mathrm{H}_{2} \mathrm{O}$ and $2 \mathrm{ml}$ of $\mathrm{HNO}_{3} 65 \%$ (Hoenig and de Kersabiec, 1996) and heated at $100{ }^{\circ} \mathrm{C}$ for $5 \mathrm{~min}$. Each solution was filtered and diluted in $\mathrm{H}_{2} \mathrm{O}$ in order to obtain a $25 \mathrm{ml}$ solution. $\mathrm{Cu}_{\mathrm{pl}}$ and $\mathrm{Co}_{\mathrm{pl}}$ were determined by inductively coupled plasma mass spectrometry (ICP- MS) (Thermo Scientific XSERIES2).

\subsection{Soil analyses}

A soil sample (approximately $50 \mathrm{~g}$ dry weight) from the rhizosphere of each sampled plant was collected. Each sample was air dried for one week and sieved at $2 \mathrm{~mm}$ before analysis. Rock (gravel) content was assessed as the (1 - mass proportion) of the $2 \mathrm{~mm}$ sieved dried soil. Soil $\mathrm{pH}$ was measured with a glass electrode on a 5:1 demineralised water:soil sample. Organic matter content was measured by calcination for $12 \mathrm{~h}$ at $550{ }^{\circ} \mathrm{C}$ on $2 \mathrm{~g}$ soil samples that were previously heated at $105^{\circ} \mathrm{C}$ for $48 \mathrm{~h}$ in order to remove any interstitial water (Pansu and Gautheyrou, 2006). Mineral elements were extracted with $1 \mathrm{M}$ ammonium acetate-EDTA (pH 4.65) for $60 \mathrm{~min}$ using $5 \mathrm{~g}$ of dry soil in $25 \mathrm{ml}$ of solution (Cottenie et al., 1982). The supernatant was filtered and analysed by inductively coupled plasma-optical emission spectrometers (ICP-OES; Vista MPX, Varian Inc., Palo Alto, CA, USA) for the following elements: $\mathrm{Cu}, \mathrm{Co}, \mathrm{Mn}, \mathrm{Mg}, \mathrm{P}, \mathrm{K}$ and Fe.

\subsection{Statistical analysis}

Soil parameters were log-transformed if necessary before analysis to meet normality assumptions. Variation of soil properties was explored with a principal component analysis. Soil copper was highly correlated with the first principal component (see Supplementary material 1, fig. S1). On copper hills, copper is known to have a strong filtering effect on vegetation structure (Séleck et al., 2013) and functional traits variation (Delhaye et al., 2016). For these reasons, soil copper was selected as the main gradient of interest in further analyses. The association between soil $\mathrm{Cu}$ content and other soil parameters at each site were quantified using Pearson correlation coefficient (see also Supplementary material 1).

Traits were log-transformed if necessary to meet the normality assumption. Within each site, the amplitude of variation of traits was evaluated using the coefficient of variation (CV) and trait min-max range. To test if large variability in soil conditions induces large variability in functional traits, Spearman correlations between traits CV or range and the range of soil $\mathrm{Cu}$ content at each site were used. Species level patterns of traits variation were evaluated by comparing the fit of a linear and a quadratic regression on the data, pooling the five populations. The best model was selected based on AICc criterion. When the difference in AICc $<2$ (Burnham and Anderson, 2004), the linear model was selected. To identify other potentially important soil factors, a redundancy analysis (RDA) was performed to quantify the multivariate variation of traits explained by all soil factors (see methods and results in Supplementary material 1). Using this methodology, soil $\mathrm{Cu}$ was the factor explaining the most variation and was therefore further used as main gradient of interest.

To assess the relative contributions of intra- and inter-site variance to the total trait variance, a set of linear models were built. For each of the 8 traits, three different models were produced to extract the proportion of variance $\left(\mathrm{R}^{2}\right)$ explained by the site effect and the local soil copper gradient at each site. The first model uses a simple linear regression where soil copper is the only explanatory variable $\left(\mathrm{R}^{2}{ }_{1}\right)$. This produces a single model forcing the same slope and intercept for all sites. The second model is a linear mixed model in which soil copper is the fixed effect and the site is a random effect $\left(\mathrm{R}^{2}{ }_{2}\right)$. This produces a regression line for each site with different intercepts but the same slope. Finally, the third is also a linear mixed model, with the soil copper content as a fixed variable and the interaction between the site and the soil copper concentration as a random variable $\left(\mathrm{R}^{2}{ }_{3}\right)$. The latter provides a random slope and random intercept model, allowing each site to have different slopes for trait variation along the copper gradient. The proportion of variance explained by the site is obtained by VarSite $=\mathrm{R}_{2}{ }_{2}-\mathrm{R}^{2}{ }_{1}$ and the proportion of variance explained by the copper gradient within each site is obtained by: VarCu*Site $=\mathrm{R}^{2}{ }_{3}-\mathrm{R}^{2}{ }_{2}$. The residual variance is calculated by VarResidual $=1-($ VarSite + VarCu*Site $)$.

Linear regressions by permutation $(n=9999)$ were conducted for all traits along the copper gradients at each site separately in order to assess the functional response of each population to within-site environmental variation. To test if the different populations show similar patterns of trait variation along the copper gradients, the slopes of regression lines were compared between sites using a covariance analysis (ANCOVA) with a designed contrast matrix to compare slopes but not the intercepts in order to reduce the number of simultaneous tests. The same methodology was also applied with all other measured soil factors as a control and none showed more significant relationships than with soil copper content, suggesting that this is the main factor driving functional traits variation (results not shown). Analyses were conducted in R software 3.0.2 (www.R-project.org) using packages lme4, ade4, ape and multcomp, vegan and proxy.

\section{Results}

3.1. Soil

Soil Ac-EDTA extractible elements, stone and organic matter contents as well as $\mathrm{pH}$, vary extensively both within and among sites (Table 1 and Supplementary material 1, fig. S1a). The range of soil Cu concentration is shortest on Goma and longest on Fungurume. In addition to $\mathrm{Cu}$, each site also shows extensive variation for other Ac-EDTA extractible elements, especially $\mathrm{Co}, \mathrm{Mn}$ and $\mathrm{Ca}$. Fungurume has the highest values in $\mathrm{Cu}, \mathrm{Co}, \mathrm{Mn}, \mathrm{Ca}, \mathrm{Mg}, \mathrm{P}$ and $\mathrm{pH}$. Goma is characterized by lower concentrations in $\mathrm{Cu}, \mathrm{Mn}$ and organic matter. Kinsevere contrasts with all the other sites by its lower Co level $\left(<17 \mathrm{mg} \mathrm{kg}^{-1}\right)$.

In all sites except Kinsevere, soil $\mathrm{Cu}$ content is strongly positively correlated to Co content (Table 2). Cu is positively correlated with $\mathrm{P}$ and organic matter, significantly so in 4 of 5 sites (P) and 3 of 5 sites (organic matter). Other correlation patterns between $\mathrm{Cu}$ and other 
Table 2

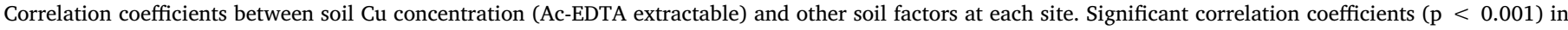
bold.

\begin{tabular}{|c|c|c|c|c|c|c|c|c|c|c|}
\hline & Co & Mn & $\mathrm{Ca}$ & $\mathrm{Fe}$ & $\mathrm{K}$ & $\mathrm{Mg}$ & $\mathrm{P}$ & Rock & MO & $\mathrm{pH}$ \\
\hline Goma & 0.95 & 0.07 & 0.09 & -0.19 & -0.28 & -0.32 & 0.74 & 0.61 & 0.05 & 0.01 \\
\hline Orthodoxe & 0.89 & 0.84 & 0.08 & 0.11 & 0.43 & 0.05 & 0.96 & 0.50 & 0.81 & -0.38 \\
\hline Zikule & 0.83 & 0.86 & 0.00 & -0.46 & -0.07 & 0.18 & 0.60 & -0.24 & 0.30 & 0.39 \\
\hline Kinsevere & -0.80 & -0.42 & 0.67 & 0.11 & 0.25 & 0.33 & 0.97 & 0.67 & 0.80 & -0.18 \\
\hline Fungurume & 0.96 & -0.60 & 0.80 & -0.71 & 0.29 & 0.24 & 0.99 & 0.57 & 0.63 & 0.70 \\
\hline
\end{tabular}
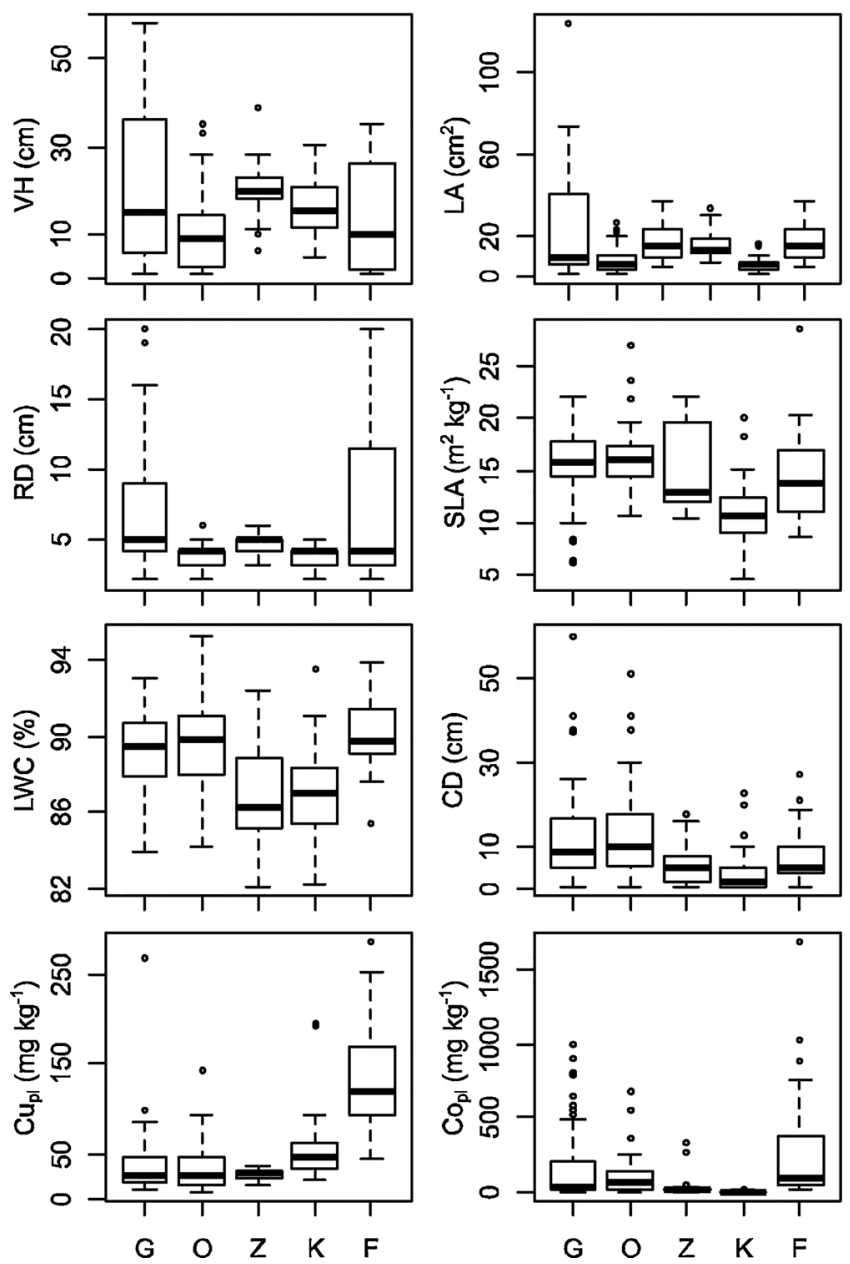

Fig. 1. Variation of eight traits for the five populations ( $G=$ Goma, $\mathrm{O}=$ Orthodoxe, $\mathrm{Z}=$ Zikule, $\mathrm{K}=$ Kinsevere, $\mathrm{F}=$ Fungurume). $\mathrm{VH}$ : vegetative height, LA: leaf area, RD: rooting depth, SLA: specific leaf area, LWC: leaf water content, $\mathrm{CD}$ : clonal distance, $\mathrm{Cu}_{\mathrm{pl}}$ and $\mathrm{Co}_{\mathrm{pl}}$ leaf $\mathrm{Cu}$ and $\mathrm{Co}$ content. The thick bar represents the median; the box contains the inter-quartile range (IQR) and the whiskers are the maximum 1.5 IQR.

elements are highly site-specific (Table 2). On Fungurume, $\mathrm{pH}$ and $\mathrm{Ca}$ concentration increase with $\mathrm{Cu}$ concentration in the soil.

\subsection{Plant traits}

There is extensive variation both within and among populations for all traits (Fig. 1 and Supplementary material 1, fig S1b). The population Goma has the largest range of size related traits and clonal distance (VH: $57 \mathrm{~cm}, \mathrm{LA}: 122 \mathrm{~mm}^{2}, \mathrm{CD}=60 \mathrm{~cm}$ ) and covers the whole range of trait values (Fig. 1). Fungurume has the highest foliar $\mathrm{Cu}$ and $\mathrm{Co}$, up to 286 and $1700 \mathrm{mg} \mathrm{kg}^{-1}$ respectively. Using both traits $\mathrm{CV}$ and range (Supplementary material 2), there is no significant correlation between traits and soil $\mathrm{Cu}$ variability- e.g. the largest variability (CV and range)
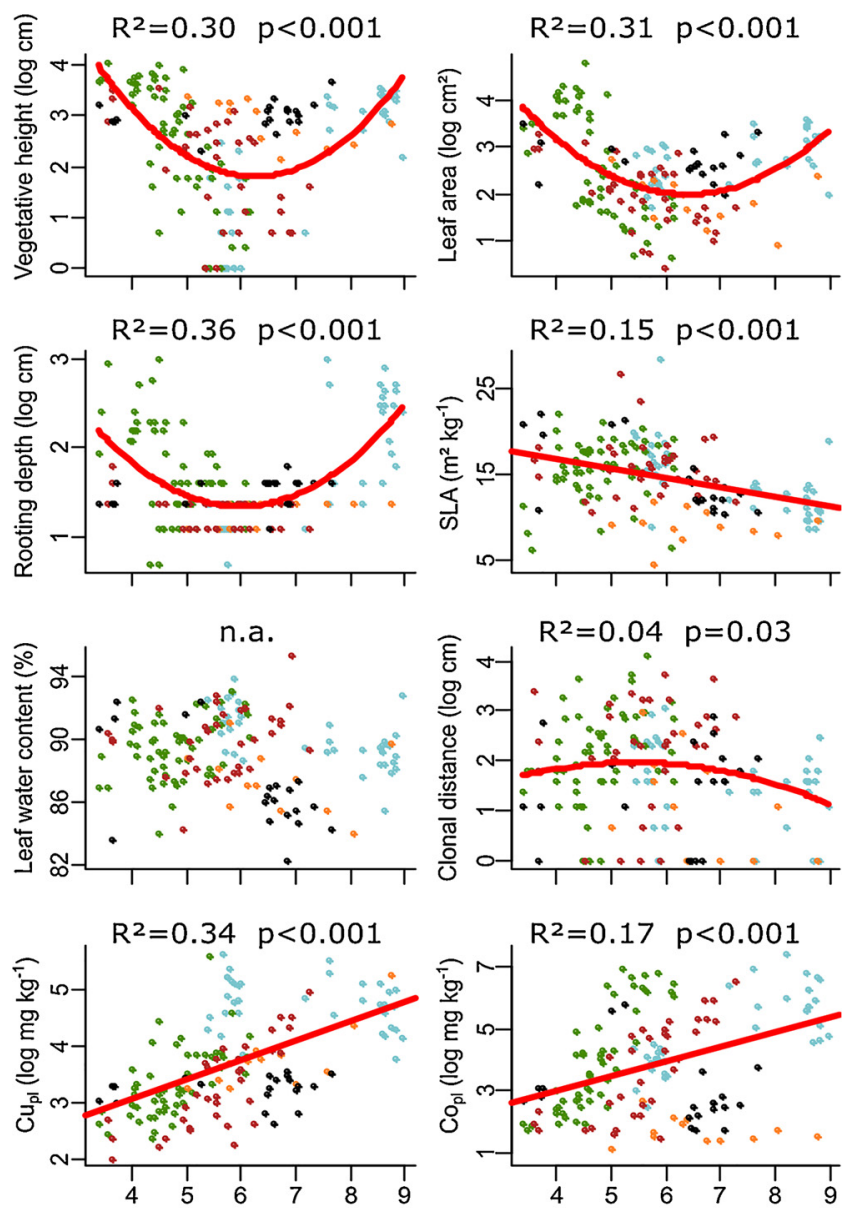

Soil $\mathrm{Cu}$ content (log $\mathrm{mg} \mathrm{kg}^{-1}$ )

Fig. 2. Trait variation at the species level, pooling the five studied populations, along the copper gradient. A linear and a quadratic model were fitted for each trait and the best model based on the AICc criterion was selected. The red line is the significant regression line. $\mathrm{R}^{2}$ and associated $\mathrm{p}$-value are reported. Colour code: Goma (green), Orthodoxe (red), Zikule (black), Kinsevere (orange), Fungurume (blue). (For interpretation of the references to colour in this figure legend, the reader is referred to the web version of this article).

in size traits are found along the shortest soil $\mathrm{Cu}$ gradient (Goma).

\subsection{Trait variation along the soil $\mathrm{Cu}$ concentration}

The patterns of variation at the species level are trait specific (Fig. 2). VH, LA and RD show a highly significant quadratic relationship with soil $\mathrm{Cu}$ concentration with higher trait value at both ends of the gradient. Three traits show significant linear regression with soil $\mathrm{Cu}$ : SLA (negative slope), $\mathrm{Cu}_{\mathrm{pl}}$ and $\mathrm{Co}_{\mathrm{pl}}$ (positive slope). Leaf water content shows no significant relationship and clonal distance shows a negligible $\left(\mathrm{R}^{2}=0.04\right)$ quadratic relationship with soil $\mathrm{Cu}$ concentration.

For size related traits (VH, LA and $\mathrm{RD}$ ) the local soil $\mathrm{Cu}$ gradient 
Table 3

Percentages of variance explained by the inter-site effect (Among site), the local soil copper gradient within each site ( $\mathrm{Cu}$ within site) and the residuals expressed as a percentage of the total variance.

\begin{tabular}{llll}
\hline & Among site & Cu within site & Residuals \\
\hline Vegetative height & 10.6 & 51.0 & 38.4 \\
Leaf area & 18.1 & 30.4 & 51.5 \\
Rooting depth & 19.6 & 28.4 & 52.0 \\
Specific leaf area & 14.3 & 9.6 & 76.1 \\
Leaf water content & 23.0 & 13.7 & 63.3 \\
Clonal distance & 10.6 & 5.2 & 84.1 \\
$\mathrm{Cu}_{\mathrm{pl}}$ & 24.6 & 14.6 & 60.8 \\
$\mathrm{Co}_{\mathrm{pl}}$ & 32.9 & 22.2 & 44.9 \\
\hline
\end{tabular}

explains between 28 and $51 \%$ of the traits variation (Table 3). For SLA, LWC and $\mathrm{CD}$, the site effect explains approximately twice more variance than the gradient effect. Interestingly, $\mathrm{Cu}_{\mathrm{pl}}$ and $\mathrm{Co}_{\mathrm{pl}}$ also show a larger site effect than the soil extractable-Cu effect (1.6 and 1.5 times respectively; Table 3).

Within each site, a linear regression analysis was conducted to examine the pattern of variation of each trait as a function of soil $\mathrm{Cu}$. For morphological traits, the regression analysis and associated covariance analysis reveal highly contrasting, site specific patterns of trait variation along the $\mathrm{Cu}$ gradients (Fig. 3, Supplementary material 3).

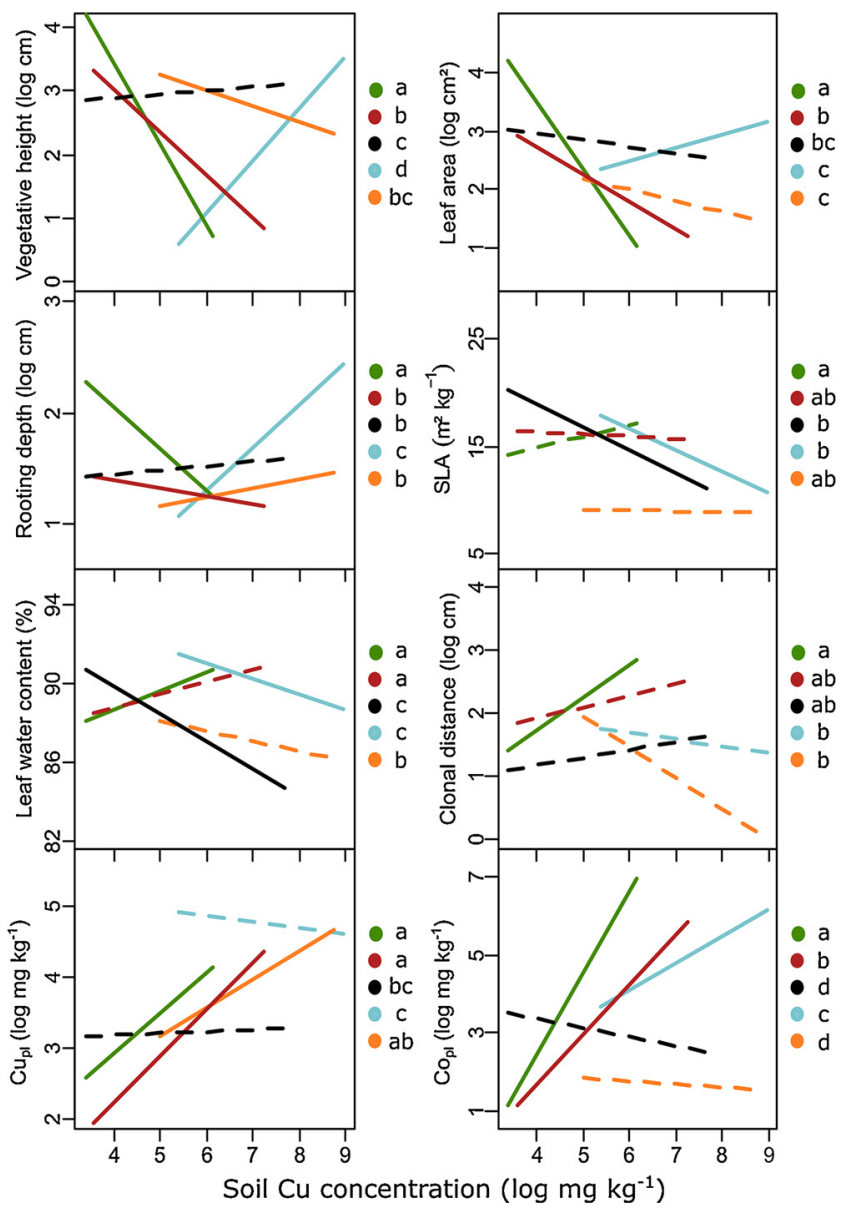

Fig. 3. Functional traits variation along the copper gradient for the five studied sites. Plain lines represent significant linear regression, dashed lines are nonsignificant. Letters in the legend represent similarities in regression slopes of the different populations for each graph (see supplementary material 3 for exact values). Colour code: Goma (green), Orthodoxe (red), Zikule (black), Kinsevere (orange), Fungurume (blue). (For interpretation of the references to colour in this figure legend, the reader is referred to the web version of this article).
Significant covariation with soil $\mathrm{Cu}$ was found in 1 to 4 sites depending on trait. Significant correlations in opposite directions were found in 4 of 8 traits (vegetative height, leaf area, rooting depth, leaf water content).

\section{Discussion}

Intraspecific trait variation is receiving increasing attention in plant community ecology (Siefert et al., 2015). However, few studies have focused on traits variation at inter and intra population levels. Here, for the first time, the relative contribution of intra and inter-population trait variation as well as patterns of traits variation in relation to MTE gradients are studied in a broad-niched metallophyte. Cyanotis longifolia is able to grow on soil with Ac-EDTA-extractable $\mathrm{Cu}$ concentration spanning more than two orders of magnitude (range: $30-7758 \mathrm{mg}$ $\mathrm{kg}^{-1}$ ). The species occurs in plant communities that show dramatic variations in floristic composition and community averaged trait values, along copper gradients (Séleck et al., 2013; Delhaye et al., 2016) which are, at least partly, due to the increase in MTE concentrations in the soil.

\subsection{Species level trait variation}

Edaphic heterogeneity has significant impact on local intraspecific trait variation, especially in broad-niched species along altitudinal, fertility or aridity gradients (Lenssen et al., 2004; Fajardo and Piper, 2011; Pakeman, 2013; Harzé et al., 2016; De Smedt et al., 2018). In this study, functional traits of a broad niched species show large variation along short distance MTE gradients (Ac-EDTA extractable). With increasing soil $\mathrm{Cu}$ concentration, $C$. longifolia shows a decrease in SLA value concomitantly with an increase in tissues MTE concentrations. This relationship could be attributed to an increasing stress tolerance strategy of the plants with increasing the soil metal toxicity (Potters et al., 2007). SLA is related to growth rate and resource use efficiency (Wright et al., 2004) and the increase of MTE concentrations in the plant tissues could induce a physiological stress while imposing an investment in metal sequestration mechanisms. The increase in MTE concentration in plant tissues is a well known feature of some species in the copper flora, especially in facultative metallophyte species (Faucon et al., 2007; Lange et al., 2018). Most surprisingly, at the species level, the covariation of size traits with soil copper was quadratic with lowest values at intermediate soil $\mathrm{Cu}$. The fact that several traits show similar patterns of response is not surprising, especially for traits related to the same functional axis, such as the plant size axis (Díaz et al., 2016). Nonlinear traits responses along environmental gradients have been previously discussed (e.g. Albert et al., 2010) but the origin of these patterns often remains unclear. Here, contrasting site specific responses account for the quadratic response at the species level along the copper concentration gradient. It should be noted however that some traits might vary due to environmental factors independent of the soil MTE toxicity. For instance, size related traits show a negative correlation with the soil rock content (see RDA results in Supplementary material 1). The increase in rock content in the soil could imply a lower water retention capacity in the soil, therefore selecting phenotypes adapted to water depletion. However, it was shown that rock content in the soil is not necessarily correlated to a decrease in soil water content in such environments (Delhaye et al., 2016). Further studies measuring other soil parameters on a larger number of sites, encompassing many different combinations of parameters, could provide further insight on the actual factors driving traits variation at the species level.

\subsection{Within population trait variation}

Along gradients of environmental harshness and within a single species, large phenotypic variations and similar directions of trait variation are generally expected due to the strong restrictive effect of 
environmental conditions on plants phenotypes (e.g. Kolbas et al., 2018). Here, an unsuspected complex pattern of trait variation within and among populations emerged. Intra population trait variations are highly site and trait specific along the studied copper gradients and account for variable proportions of total variance (between 5 and 51\%) depending on trait. This is consistent with results found along altitude or resource gradients (Wellstein et al., 2013; Lemke et al., 2015; Harzé et al., 2016; Pfennigwerth et al., 2017). Contrary to expectations, covariation with copper was less important compared to the site effect for most traits: only for size related traits was the impact of the local soil copper gradient superior to the site effect. This contradicts the results of a controlled experiment showing that most of the variation in morphological and physiological traits in another pseudometallophyte happened within population (Meyer et al., 2010). The large variation of size related traits along local gradients could indicate a trade-off between allocation to size and metal tolerance (Ernst et al., 1990). The lower intra-population variation for traits related to resources use tends to show a strong conservatism of these traits along MTE gradients. This is consistent with previously reported results along resources or climatic gradients (Fajardo and Piper, 2011; Siefert et al., 2015; Harzé et al., 2016) but is also consistent with experimental findings on a facultative metallophyte from the copper hills, where SLA vary between populations but not in response to soil metal concentration (Lange et al., 2017b). On the contrary, plants MTE contents exhibit large differences both within and between populations as found in other metallophytes (Stein et al., 2017; Frérot et al., 2018) and show different patterns of covariation with other traits. The large part of the variance explained by the site effect for the plant $\mathrm{Cu}$ and Co content (24.6 and $32.9 \%$ respectively) is likely due to the differences in soil metal concentrations as well as other factors that can influence soil MTE availability. On copper hills, $\mathrm{Cu}$ availability in the soil is strongly influenced by other edaphic factors, such as $\mathrm{pH}$ and organic matter content (Lange et al., 2014; Pourret et al., 2016). This could play an important role on Fungurume and Kinsevere, where toxicity seems less clear on functional traits and organic matter content co-vary positively with soil $\mathrm{Cu}$ content. Soil organic matter content is known to immobilize $\mathrm{Cu}$, leading to less free $\mathrm{Cu}$ ions in the soil solution (McGrath et al., 1988). Further, on Fungurume, the increase in soil $\mathrm{pH}$ and $\mathrm{Ca}$ content could be due to an increase in carbonates in the soil. Due to the high $\mathrm{pH}$ on the most contaminated soils on Fungurume, Cu could be immobilised in the soil (Kabata-Pendias, 2010) and therefore represent a less toxic constraint for plants. However, other studies show that organic matter content and $\mathrm{pH}$ could not influence the proportion of free $\mathrm{Cu}^{2+}$ content relative to the total $\mathrm{Cu}$ concentration in the soil (Sauvé et al., 1997). On Fungurume, another study shows that a few plant species exhibit a clear decrease in size related traits and an increase in tissues $\mathrm{Cu}$ content (Delhaye et al., 2016). Population level differences in metal accumulation and tolerance were also demonstrated experimentally in several copper hill metallophytes (Faucon et al., 2012; Peng et al., 2012; Lange et al., 2018) and might be driven by different MTE concentrations in the native soil, therefore suggesting genetic determinism of metal tolerance strategy at the population level. Therefore, the functional traits response to copper toxicity is likely species-specific as well as populationspecific within species. Finally, the difference in the behaviour between both $(\mathrm{Cu}$ and $\mathrm{Co}$ ) metals might be related to the greater mobility of Co at the plant-soil interface and the lack of efficient mechanism of Co detoxification (Lange et al., 2017a).

The absence of correlation between gradient length and functional traits variability in each population contradicts the hypothesis that larger niche implies larger trait variation (Sandquist and Ehleringer, 2003; Sides et al., 2014) but is consistent with observations along light availability gradients (Lemke et al., 2012). This might be due to different, site specific, mechanisms of phenotypic variation on different isolated sites or on soils with different MTE concentrations within each site. It is not known if the covariations with soil $\mathrm{Cu}$ are due to phenotypic plasticity or local adaptation. Due to the geographical isolation, site specific responses of traits along local gradients may have evolved due to genetic drift (e.g. Vellend, 2010) or local adaptation (Kawecki and Ebert, 2004). Short distance genetic differentiation was demonstrated along different types of environmental gradients such as altitude (Byars et al., 2007; Leempoel et al., 2018) or in response to short distance variation in metal contamination (Jain and Bradshaw, 1966; Antonovics et al., 1971). Therefore, phenotypic plasticity could be the main mechanism of functional adjustment along short gradients (e.g. at Goma) while local adaptation could appear along large gradients in soil MTE concentrations (e.g. at Fungurume). This might explain the apparent distinct groups of individuals on soil with low and high metal content within the population of Fungurume (see Supplementary material 1, Fig. S1). This hypothesis could be tested using genetic analysis and common garden experiments.

Traits covariation is also recognised as an important factor explaining the local diversity of phenotypes (Armbruster and Schwaegerle, 1996). Trade-offs between traits can produce different local phenotypes selected in particular environments (Laughlin and Messier, 2015). Finally, it is likely that other environmental factors such as mycorrhizal fungi or bacteria could improve plants MTE tolerance (Lenoir et al., 2016; Sun et al., 2010) and are also influenced by local soil conditions (Bauman et al., 2016). Therefore, we further advocate for experimental measurement of the variation in population level traits along $\mathrm{Cu}$ and/or Co gradients in controlled conditions (Lange et al., 2017b) in order to disentangle the relative proportion of phenotypic plasticity and ecotypic variation in $C$. longifolia.

\section{Conclusion}

Our study has revealed a complex pattern in the structure of intraspecific variation in a broad niched species. This suggests that generalization based on one or very few populations may be highly misleading due to the particular combination of local conditions at each site. A species should be sampled from sites encompassing its whole ecological range. Our results also stress that, depending on the spatial scale at which intraspecific variation is explored, very different patterns can emerge. This is likely due to interactions between isolation, various edaphic factors and/or local adaptation. A population specific approach is needed to capture the whole species level traits variation along toxicity gradient.

\section{Declarations of interest}

None.

\section{CRediT authorship}

Guillaume Delhaye: Conceptualization, Methodology, Software, Formal analysis, Investigation, Data Curation, Writing - Original Draft, Review \& Editing. Bastien Lange: Formal analysis, Investigation, Writing - Review \& Editing. Michel-Pierre Faucon: Resources, WritingReview \& Editing. Céline Grandjean: Conceptualization, Methodology, Formal analysis, Investigation. Gregory Mahy: Resources, Writing Review \& Editing. Pierre Meerts: Conceptualization, Methodology, Resources, Writing - Original Draft, Review \& Editing, Supervision.

\section{Acknowledgments}

GD is grateful to Kristel Wart and Alexandre Van Baekel for help with plant and soil analysis, to Gilles San Martin and David Bauman for useful statistical advice during data analysis and to Arnaud Jacobs for interesting discussions and comments on a draft.

\section{Appendix A. Supplementary data}

Supplementary material related to this article can be found, in the 
online version, at doi:https://doi.org/10.1016/j.envexpbot.2018.09. 001.

\section{References}

Albert, C.H., Thuiller, W., Yoccoz, N.G., Soudant, A., Boucher, F., Saccone, P., Lavorel, S., 2010. Intraspecific functional variability: extent, structure and sources of variation. J. Ecol. 98, 604-613.

Al-Hiyaly, S.A.K., McNeilly, T., Bradshaw, A.D., Mortimer, A.M., 1993. The effect of zinc contamination from electricity pylons. Genetic constraints on selection for zinc tolerance. Heredity $70,22-32$.

Antonovics, J., Bradshaw, A.D., Turner, R.G., 1971. Heavy metal tolerance in plants. Adv. Ecol. Res. 7, 1-85.

Armbruster, W.S., Schwaegerle, K.E., 1996. Causes of covariation of phenotypic traits among populations. J. Evol. Biol. 9, 261-276.

Baker, A.J., Ernst, W.H., van der Ent, A., Malaisse, F., Ginocchio, R., 2010. Metallophytes: the unique biological resource, its ecology and conservational status in Europe, central Africa and Latin America. In: Batty, L.C., Hallberg, K.B. (Eds.), Ecology of Industrial Pollution, pp. 7-40.

Bauman, D., Raspe, O., Meerts, P., Degreef, J., Ilunga Muledi, J., Drouet, T., 2016. Multiscale assemblage of an ectomycorrhizal fungal community: the influence of host functional traits and soil properties in a 10-ha miombo forest. FEMS Microbiol. Ecol. 92. https://doi.org/10.1093/femsec/fiw151.

Bradshaw, A.D., 1959. Population differentiation in Agrostis tenuis sibth. New Phytol. 58, 208-227.

Bresson, C.C., Vitasse, Y., Kremer, A., Delzon, S., 2011. To what extent is altitudinal variation of functional traits driven by genetic adaptation in European oak and beech? Tree Physiol. 31, 1164-1174.

Burnham, K.P., Anderson, D.R., 2004. Multimodel inference: understanding AIC and BIC in model selection. Sociol. Methods Res. 33, 261-304.

Byars, S.G., Papst, W., Hoffmann, A.A., 2007. Local adaptation and cogradient selection in the alpine plant, Poa hiemata, along a narrow altitudinal gradient. Evolution 61, 2925-2941.

Cottenie, A., Verloo, M., Kiekens, L., Velghe, G., Camerlynck, R., 1982. Chemical Analysis of Plants and Soils. Instituut tot Aanmoediging van het Wetenschappelijk Onderzoek in Nijverheid en Landbouw (I.W.O.N.L.), Brussels.

De Smedt, P., Ottaviani, G., Wardell-Johnson, G., Sýkora, K.V., Mucina, L., 2018. Habitat heterogeneity promotes intraspecific trait variability of shrub species in Australian granite inselbergs. Folia Geobot. 53, 133-145.

Delhaye, G., Violle, C., Séleck, M., Ilunga wa Ilunga, E., Daubie, I., Mahy, G., Meerts, P., 2016. Community variation in plant traits along copper and cobalt gradients. J. Veg. Sci. $27,854-864$.

Díaz, S., Kattge, J., Cornelissen, J.H., Wright, I.J., Lavorel, S., Dray, S., et al., 2016. The global spectrum of plant formand function. Nature 529, 167-171.

Duvigneaud, P., Denaeyer-De Smet, S., 1963. Cuivre et végétation au Katanga. Bulletin de la Société Royale de Botanique de Belgique 96, 93-231.

Ernst, W.H.O., Schat, H., Verkleij, J.A.C., 1990. Evolutionary biology of metal resistance in Silene vulgaris. Evol. Trends Plants 4, 45-51.

Faden, R.B., 2012. Flora of Tropical East Africa: Commelinaceae. Royal Botanic Gardens, Kew.

Fajardo, A., Piper, F.I., 2011. Intraspecific trait variation and covariation in a widespread tree species (Nothofagus pumilio) in southern Chile. New Phytol. 189, 259-271.

Faucon, M.P., Shutcha, M.N., Meerts, P., 2007. Revisiting copper and cobalt concentrations in supposed hyperaccumulators from SC Africa: influence of washing and metal concentrations in soil. Plant Soil 301, 29-36.

Faucon, M.P., Chipeng, F., Verbruggen, N., Mahy, G., Colinet, G., Shutcha, M., et al., 2012. Copper tolerance and accumulation in two cuprophytes of South Central Africa: crepidorhopalon perennis and C. Tenuis (Linderniaceae). Environ. Exp. Bot. 84, $11-16$.

Faucon, M.P., Le Stradic, S., Boisson, S., wa Ilunga, E.I., Séleck, M., Lange, B., et al., 2016. Implication of plant-soil relationships for conservation and restoration of coppercobalt ecosystems. Plant Soil 403, 153-165.

Frérot, H., Hautekèete, N.C., Decombeix, I., Bouchet, M.H., Créach, A., SaumitouLaprade, P., et al., 2018. Habitat heterogeneity in the pseudometallophyte Arabidopsis halleri and its structuring effect on natural variation of zinc and cadmium hyperaccumulation. Plant Soil 423, 157-174.

Garnier, E., Cortez, J., Billès, G., Navas, M.L., Roumet, C., Debussche, M., et al., 2004. Plant functional markers capture ecosystem properties during secondary succession. Ecology 85, 2630-2637.

Harper, F.A., Smith, S.E., Macnair, M.R., 1997. Where is the cost in copper tolerance in Mimulus guttatus? Testing the trade-off hypothesis. Funct. Ecol. 11, 764-774.

Hart, S.P., Schreiber, S.J., Levine, J.M., 2016. How variation between individuals affects species coexistence. Ecol. Lett. 19, 825-838.

Harzé, M., Mahy, G., Monty, A., 2016. Functional traits are more variable at the intrathan inter-population level: a study of four calcareous dry-grassland plant species. Tuexenia 36, 321-336.

Hoenig, M., de Kersabiec, A.M., 1996. Sample preparation steps for analysis by atomic spectroscopy methods: present status. Spectrochim. Acta Part B At. Spectrosc. 51, $1297-1307$.

Ilunga wa Ilunga, E., Séleck, M., Colinet, G., Faucon, M.P., Meerts, P., Mahy, G., 2013. Small-scale diversity of plant communities and distribution of species niches on a copper rock outcrop in Upper Katanga, DR Congo. Plant Ecol. Evol. 146, 173-182.

Jain, S.K., Bradshaw, A.D., 1966. Evolutionary divergence among adjacent plant populations I. The evidence and its theoretical analysis. Heredity 21, 407-441.
Kabata-Pendias, A., 2010. Trace Elements in Soils and Plants. CRC press.

Kawecki, T.J., Ebert, D., 2004. Conceptual issues in local adaptation. Ecol. Lett. 7, 1225-1241.

Kolbas, A., Kolbas, N., Marchand, L., Herzig, R., Mench, M., 2018. Morphological and functional responses of a metal-tolerant sunflower mutant line to a copper-contaminated soil series. Environ. Sci. Pollut. Res. - Int. 25, 16686-16701.

Lange, B., Faucon, M.P., Meerts, P., Shutcha, M., Mahy, G., Pourret, O., 2014. Prediction of the edaphic factors influence upon the copper and cobalt accumulation in two metallophytes using copper and cobalt speciation in soils. Plant Soil 379, 275-287.

Lange, B., Ent, A., Baker, A.J.M., Echevarria, G., Mahy, G., Malaisse, F., et al., 2017a. Copper and cobalt accumulation in plants: a critical assessment of the current state of knowledge. New Phytol. 213, 537-551.

Lange, B., Faucon, M.P., Delhaye, G., Hamiti, N., Meerts, P., 2017b. Functional traits of a facultative metallophyte from tropical Africa: population variation and plasticity in response to cobalt. Environ. Exp. Bot. 136, 1-8.

Lange, B., Delhaye, G., Boisson, S., Verbruggen, N., Meerts, P., Faucon, M.P., 2018. Variation in copper and cobalt tolerance and accumulation among six populations of the facultative metallophyte Anisopappus chinensis (Asteraceae). Environ. Exp. Bot. $153,1-9$.

Laughlin, D.C., Messier, J., 2015. Fitness of multidimensional phenotypes in dynamic adaptive landscapes. Trends Ecol. Evol. 30, 487-496.

Leempoel, K., Parisod, C., Geiser, C., Joost, S., 2018. Multiscale landscape genomic models to detect signatures of selection in the alpine plant Biscutella laevigata. Ecol. Evol. 8, 1794-1806.

Lefebvre, C., 1974. Population variation and taxonomy in Armeria maritima with special reference to heavy-metal tolerant populations. New Phytol. 209-219.

Lemke, I.H., Kolb, A., Diekmann, M.R., 2012. Region and site conditions affect phenotypic trait variation in five forest herbs. Acta Oecologica 39, 18-24.

Lemke, I.H., Kolb, A., Graae, B.J., De Frenne, P., Acharya, K.P., Blandino, C., et al., 2015. Patterns of phenotypic trait variation in two temperate forest herbs along a broad climatic gradient. Plant Ecol. 216, 1523-1536.

Lenoir, I., Lounes-Hadj Sahraoui, A., Fontaine, J., 2016. Arbuscular mycorrhizal fungal-assisted phytoremediation of soil contaminated with persistent organic pollutants: a review. Eur. J. Soil Sci. 67, 624-640.

Lenssen, J.P., Van Kleunen, M., Fischer, M., De Kroon, H., 2004. Local adaptation of the clonal plant Ranunculus reptans to flooding along a small-scale gradient. J. Ecol. 92, 696-706.

Linhart, Y.B., Grant, M.C., 1996. Evolutionary significance of local genetic differentiation in plants. Annu. Rev. Ecol. Syst. 27, 237-277.

Malaisse, F., Grégoire, J., Morrison, R.S., Brooks, R.R., Reeves, R.D., 1979. Copper and cobalt in vegetation of Fungurume, Shaba Province, zaïre. Oikos 33, 472-478.

McGrath, S.P., Sanders, J.R., Shalaby, M.H., 1988. The effects of soil organic matter levels on soil solution concentrations and extractabilities of manganese, zinc and copper. Geoderma 42, 177-188.

Meyer, C.L., Kostecka, A.A., Saumitou-Laprade, P., Créach, A., Castric, V., Pauwels, M., Frérot, H., 2010. Variability of zinc tolerance among and within populations of the pseudometallophyte species Arabidopsis halleri and possible role of directional selection. New Phytol. 185, 130-142.

Owens, S.J., 1981. Self-incompatibility in the Commelinaceae. Ann. Bot. 47, 567-581.

Pakeman, R.J., 2013. Intra-specific leaf trait variation: management and fertility matter more than the climate at continental scales. Folia Geobot. 48, 355-371.

Pansu, M., Gautheyrou, J., 2006. Handbook of Soil Analysis-mineralogical, Organic and Inorganic Methods. Springer, Berlin, Heidelberg, New-York.

Peng, H., Wang-Müller, Q., Witt, T., Malaisse, F., Küpper, H., 2012. Differences in Copper Accumulation and Copper Stress Between Eight Populations of Haumaniastrum Katangense. Environ. Exp. Bot. 79, 58-65.

Pérez-Harguindeguy, N., Díaz, S., Garnier, E., Lavorel, S., Poorter, H., Jaureguiberry, P., Harte, Bret, et al., 2013. New handbook for standardised measurement of plant functional traits worldwide. Aust. J. Bot. 61, 167-234.

Pfennigwerth, A.A., Bailey, J.K., Schweitzer, J.A., 2017. Trait variation along elevation gradients in a dominant woody shrub is population-specific and driven by plasticity. AoB Plants 9https://doi.org/10.1093/aobpla/plx027. plx027.

Potters, G., Pasternak, T.P., Guisez, Y., Palme, K.J., Jansen, M.A., 2007. Stress-induced morphogenic responses: growing out of trouble? Trends Plant Sci. 12, 98-105.

Pourret, O., Lange, B., Bonhoure, J., Colinet, G., Decrée, S., Mahy, G., et al., 2016. Assessment of soil metal distribution and environmental impact of mining in Katanga (Democratic Republic of Congo). Appl. Geochem. 64, 43-55.

Robson, T.M., Sánchez-Gómez, D., Cano, F.J., Aranda, I., 2012. Variation in functional leaf traits among beech provenances during a Spanish summer reflects the differences in their origin. Tree Genet. Genomes 8, 1111-1121.

Saad, L., Parmentier, I., Colinet, G., Malaisse, F., Faucon, M.P., Meerts, P., Mahy, G., 2012. Investigating the vegetation-soil relationships on the copper-cobalt rock outcrops of Katanga (DR Congo), an essential step in a biodiversity conservation plan. Restor. Ecol. 20, 405-415.

Sandquist, D.R., Ehleringer, J.R., 2003. Population-and family-level variation of brittlebush (Encelia farinosa, Asteraceae) pubescence: its relation to drought and implications for selection in variable environments. Am. J. Bot. 90, 1481-1486.

Sauvé, S., McBride, M.B., Norvell, W.A., Hendershot, W.H., 1997. Copper solubility and speciation of in situ contaminated soils: effects of copper level, $\mathrm{pH}$ and organic matter. Water Air Soil Pollut. 100, 133-149.

Séleck, M., Bizoux, J.P., Colinet, G., Faucon, M.P., Guillaume, A., Meerts, P., et al., 2013. Chemical soil factors influencing plant assemblages along copper-cobalt gradients: implications for conservation and restoration. Plant Soil 373, 455-469.

Sides, C.B., Enquist, B.J., Ebersole, J.J., Smith, M.N., Henderson, A.N., Sloat, L.L., 2014. Revisiting Darwin's hypothesis: does greater intraspecific variability increase species' ecological breadth? Am. J. Bot. 101, 56-62. 
Siefert, A., Violle, C., Chalmandrier, L., Albert, C.H., Taudiere, A., Fajardo, A., et al., 2015. A global meta-analysis of the relative extent of intraspecific trait variation in plant communities. Ecol. Lett. 18, 1406-1419.

Słomka, A., Sutkowska, A., Szczepaniak, M., Malec, P., Mitka, J., Kuta, E., 2011. Increased genetic diversity of Viola tricolor L.(Violaceae) in metal-polluted environments. Chemosphere 83, 435-442.

Souto, C.P., Premoli, A.C., Reich, P.B., 2009. Complex bioclimatic and soil gradients shape leaf trait variation in Embothrium coccineum (Proteaceae) among austral forests in Patagonia. Rev. Chil. Hist. Nat. 82, 209-222.

Stein, R.J., Höreth, S., Melo, J.R.F., Syllwasschy, L., Lee, G., Garbin, M.L., et al., 2017. Relationships between soil and leaf mineral composition are element-specific, environment-dependent and geographically structured in the emerging model Arabidopsis halleri. New Phytol. 213, 1274-1286.

Sun, L.N., Zhang, Y.F., He, L.Y., Chen, Z.J., Wang, Q.Y., Qian, M., Sheng, X.F., 2010. Genetic diversity and characterization of heavy metal-resistant-endophytic bacteria from two copper-tolerant plant species on copper mine wasteland. Bioresour. Technol. 101, 501-509.

Valladares, F., Matesanz, S., Guilhaumon, F., Araujo, M., Balaguer, L., Benito-Garzón, M.,
Cornwell, W., Gianoli, E., van Kleunen, M., Naya, D.E., Nicotra, A., Poorter, H., Zavala, M.A., 2014. The effects of phenotypic plasticity and local adaptation on forecasts of species range shifts under climate change. Ecol. Lett. 17, 1351-1364. Vellend, M., 2010. Conceptual synthesis in community ecology. Q. Rev. Biol. 85, 183-206.

Vojtkó, A.E., Freitag, M., Bricca, A., Martello, F., Moreno Compañ, J., Küttim, M., Kun, R., de Bello, F., Klimešová, J., Götzenberger, L., 2017. Clonal vs leaf-height-seed (LHS) traits: which are filtered more strongly across habitats? Folia Geobot. 52, 269-281.

Wellstein, C., Chelli, S., Campetella, G., Bartha, S., Galiè, M., Spada, F., Canullo, R., 2013. Intraspecific phenotypic variability of plant functional traits in contrasting mountain grasslands habitats. Biodivers. Conserv. 22, 2353-2374.

Wilson, J.B., 1988. The cost of heavy-metal tolerance: an example. Evolution 42,

$$
\text { 408-413. }
$$

Wójcik, M., Dresler, S., Tukiendorf, A., 2015. Physiological mechanisms of adaptation of Dianthus carthusianorum $\mathrm{L}$. To growth on a $\mathrm{Zn}-\mathrm{Pb}$ waste deposit-the case of chronic multi-metal and acute Zn stress. Plant Soil 390, 237-250.

Wright, I.J., Reich, P.B., Westoby, M., Ackerly, D.D., Baruch, Z., Bongers, F., et al., 2004 The worldwide leaf economics spectrum. Nature 428, 821-827. 